\title{
Biofortification of UK food crops with selenium
}

\author{
Martin R. Broadley ${ }^{1} * \dagger$, Philip J. White ${ }^{2 *}$, Rosie J. Bryson ${ }^{3}$, Mark C. Meacham ${ }^{1}$, Helen C. Bowen ${ }^{2}$, \\ Sarah E. Johnson ${ }^{2}$, Malcolm J. Hawkesford ${ }^{4}$, Steve P. McGrath ${ }^{4}$, Fang-Jie Zhao ${ }^{4}$, Neil Breward ${ }^{5}$, \\ Miles Harriman ${ }^{6}$ and Mark Tucker ${ }^{6}$ \\ ${ }^{1}$ Plant Sciences Division, University of Nottingham, Sutton Bonington, Loughborough LE12 5RD, UK \\ ${ }^{2}$ Warwick HRI, University of Warwick, Wellesbourne, Warwick CV35 9EF, UK \\ ${ }^{3}$ Velcourt Ltd, NIAB Annex, Huntingdon Road, Cambridge CB3 OLE, UK \\ ${ }^{4}$ Rothamsted Research, Harpenden, Hertfordshire AL5 2JQ, UK \\ ${ }^{5}$ British Geological Survey, Keyworth, Nottingham NG12 5GG, UK \\ ${ }^{6}$ Yara UK, Immingham Dock, Lincolnshire DN40 2NS, UK
}

\begin{abstract}
Se is an essential element for animals. In man low dietary Se intakes are associated with health disorders including oxidative stress-related conditions, reduced fertility and immune functions and an increased risk of cancers. Although the reference nutrient intakes for adult females and males in the UK are 60 and $75 \mu \mathrm{g} \mathrm{Se} / \mathrm{d}$ respectively, dietary Se intakes in the UK have declined from $>60 \mu \mathrm{g} \mathrm{Se} / \mathrm{d}$ in the $1970 \mathrm{~s}$ to $35 \mu \mathrm{g} \mathrm{Se} / \mathrm{d}$ in the 1990s, with a concomitant decline in human Se status. This decline in Se intake and status has been attributed primarily to the replacement of milling wheat having high levels of grain Se and grown on high-Se soils in North America with UK-sourced wheat having low levels of grain Se and grown on low-Se soils. An immediate solution to low dietary Se intake and status is to enrich UK-grown food crops using Se fertilisers (agronomic biofortification). Such a strategy has been adopted with success in Finland. It may also be possible to enrich food crops in the longer term by selecting or breeding crop varieties with enhanced Se-accumulation characteristics (genetic biofortification). The present paper will review the potential for biofortification of UK food crops with Se.
\end{abstract}

Agronomy: Diet: Fertilisers: Genetics: Plants: Selenium

\section{Physical, chemical and biological properties of selenium}

$\mathrm{Se}$ is a naturally-occurring oxygen-group (group VIA) element (for review, see Fordyce, 2005). Se has an atomic mass of approximately 79 and six natural isotopes exist, ${ }^{74} \mathrm{Se},{ }^{76} \mathrm{Se},{ }^{77} \mathrm{Se},{ }^{78} \mathrm{Se},{ }^{80} \mathrm{Se}$ and ${ }^{82} \mathrm{Se}$. It is a chalcophile ('S-loving') element, replacing $\mathrm{S}$ in common sulfide minerals such as pyrite, chalcopyrite, pyrrhotite and sphalerite. It also forms several rare minerals including crookesite $\left((\mathrm{Cu}, \mathrm{Tl}, \mathrm{Ag})_{2} \mathrm{Se}\right)$, berzelianite $\left(\mathrm{Cu}_{2} \mathrm{Se}\right)$ and tiemannite (HgSe). Se exists in four main oxidation states, -2 (selenide), 0 (elemental Se), +4 (selenite) and +6 (selenate), and is highly mobile under oxidising conditions, although its mobility decreases with decreasing $\mathrm{pH}$ (Gondi et al. 1992). Se is immobile under reducing conditions; elemental Se or metal selenides will form in conditions of low
$\mathrm{H}^{+}(\mathrm{pH})$ and electron (pe/Eh; a measure of the tendency of a chemical system to undergo redox reactions) activity. The solution chemistry of Se is principally (oxy)anionic, with selenite $\left(\mathrm{SeO}_{3}{ }^{2-}\right)$ and selenate $\left(\mathrm{SeO}_{4}{ }^{2-}\right)$ corresponding to sulfite and sulfate, although elemental $\mathrm{Se}$ is also stable over a wide $\mathrm{pH}$ range under reducing conditions (Brookins, 1987). Selenate is the major species in soil solution at high redox $(\mathrm{pe}+\mathrm{pH}>15)$. In the medium redox range (pe $+\mathrm{pH} 7 \cdot 5-15)$ selenite species predominate. Selenide species are stable only at low redox $(\mathrm{pe}+\mathrm{pH}<7 \cdot 5$; Elrashidi et al. 1987, 1989). In contrast with $S$ species, the lower redox state $(+4$; selenite) is more stable than the higher redox state $(+6$; selenate). Mobile selenate entering a drainage system is readily reduced to selenite if pe/Eh falls, whilst at lower $\mathrm{pH}$ levels selenite is likely to be strongly absorbed by hydrous secondary iron oxides and, to a lesser extent, by clays and organic matter.

\footnotetext{
*These authors contributed equally.

Abbreviations: HAST, high-affinity sulfate transporter; Sec, selenocysteine.

†Corresponding author: Dr Martin Broadley, fax + 440115951 6334, email martin.broadley@nottingham.ac.uk
} 
$\mathrm{Se}$ is a biologically-active element that can form direct $\mathrm{Se}-\mathrm{C}$ bonds, which occur in a range of organic compounds including selenoamino acids and selenoproteins. Selenoproteins have essential functional roles in a wide array of prokaryotes, archaebacteria and eukaryotes (Driscoll \& Copeland, 2003; Castellano et al. 2004). Se is incorporated into selenoproteins as the twenty-first amino acid selenocysteine (Sec), which is encoded by an UGA codon in the selenoprotein mRNA. Since UGA is normally read as a stop codon, the translation of selenoproteins requires several factors including a cis-acting Sec insertion sequence (frequently located in the $3^{\prime}$ untranslated region of selenoprotein genes), a novel Sec-charged tRNA that contains the anticodon UCA on which Sec is universally synthesised and additional trans-acting factors that allow delivery of Sec-tRNA ${ }^{\mathrm{Sec}}$ to the ribosome (Driscoll \& Copeland, 2003). About twenty-five to thirty Seccontaining proteins have been identified in eukaryotes, although these proteins are not distributed evenly amongst taxa; for example, selenoproteins have not yet been found in yeast and land plants. In organisms whose genomes lack Sec-containing genes selenoprotein homologues occur in which $\mathrm{Sec}$ is replaced by cysteine (Castellano et al. 2004).

\section{Selenium inputs to soils}

The Se concentrations of most soils in the world are low (normal range $0.01-2.0 \mathrm{mg} \mathrm{Se} / \mathrm{kg}$; mean $0.4 \mathrm{mg} \mathrm{Se} / \mathrm{kg}$ ), although concentrations $\leq 1200 \mathrm{mg} \mathrm{Se} / \mathrm{kg}$ can occur in seleniferous soils (Fordyce, 2005). The Se content of most soils is primarily under geological control, and high-Se soils are associated with particular shales, sandstones, limestones and slate and coal series, including those formed in Cretaceous, Jurassic, Triassic, Carboniferous, Ordovician and Permian periods (Fordyce, 2005). Seleniferous soils are widespread in the Great Plains of the USA, Canada, South America, China and Russia. Other notable inputs of Se to soils include atmospheric deposition of Se originating from volcanic activity, weathering of rocks, sea spray and volatilisation-recycling from biota. All these factors contribute to global Se cycling. In the UK atmospheric Se deposition is approximately $2 \cdot 2-6.5 \mathrm{~g} \mathrm{Se} / \mathrm{ha}$ per year (Fordyce, 2005). Anthropogenic sources of Se to soils arise from fossil fuel combustion, metal processing, applications of fertilisers, lime and manure, and disposal of sewage sludge (Fordyce, 2005). Se from fossil fuel combustion and metal processing is deposited to soils predominantly in rainwater, which contains $0.00001-0.001 \mathrm{mg} \mathrm{Se} / 1$ (De Gregori et al. 2002). A correlation between the intensity of coal combustion and Se deposition has been observed in the Se content of historical plant samples (Haygarth et al. 1993). The use of fertilisers and irrigation water containing Se will also contribute to soil Se inputs in certain areas. For example, $\left(\mathrm{NH}_{4}\right)_{2} \mathrm{SO}_{4}$ fertilisers contain $\leq 36 \mathrm{mg} \mathrm{Se} / \mathrm{kg}$, whilst phosphate rocks and single superphosphate can contain $\leq 55 \mathrm{mg} \mathrm{Se} / \mathrm{kg}$ and $\leq 25 \mathrm{mg} \mathrm{Se} / \mathrm{kg}$ respectively (White et al. 2004). Since single superphosphate has generally been replaced by triple superphosphate, which typically contains $<4 \mathrm{mg} \mathrm{Se} / \mathrm{kg}$, fertiliser inputs of Se to soils have fallen in recent years in many parts of the world.

\section{Selenium concentration of UK soils and stream sediments}

The British Geological Survey has been surveying the baseline geochemistry of UK drainage sediments in streams, water samples and soils since the late 1960s (Geochemical Baseline Survey of the Environment; Johnson \& Breward, 2004). For Se, soils and/or stream sediments in Wales and in the Midlands of England have been sampled at a density of one to two samples per $\mathrm{km}^{2}$. Samples of stream sediments and surface waters have been analysed for Se in Wales and the west Midlands, whilst in the Humber-Trent drainage basin and in the east Midlands soils, stream sediments and surface waters have been analysed for Se (Fig. 1). From these data it can be observed that total Se in soils and stream sediments in the UK range from $0 \cdot 1 \mathrm{mg} \mathrm{Se} / \mathrm{kg}$ to $4 \mathrm{mg} \mathrm{Se} / \mathrm{kg}$, with $>95 \%$ of the UK soils containing $<1 \mathrm{mg} \mathrm{Se} / \mathrm{kg}$. Despite the low abundances of this strongly chalcophile element there is a good resolution of Se-enriched features in restricted areas.

In Wales stream-sediment Se concentrations are primarily under geological control, including sulfide mineralisation in Snowdonia, with secondary mixed ironmanganese oxide enrichment in mid-Wales and industrial contamination in the south Wales coalfield and in the industrial west Midlands (Fig. 1(a)). Strong sulfateselenate associations occur in the Triassic terrain of the Worcester and Stafford basins related to the evaporitic component of the Mercia Mudstone group. In HumberTrent stream sediments and soils (Fig. 1(b,c)) Se concentrations are high over the basinal Visean deposits and lower parts of the Namurian deposits in the south-west of the region where there is a well-developed Black Shale sequence within the Widmerpool Formation. Se concentrations are also high over the area of the Trent Valley between Newark and Gainsborough, where the Quaternary alluvial sediments may contain material derived from the former area. One isolated Se anomaly is attributable to coal waste adjacent to a power station. Relatively high values also follow the Permian and Jurassic limestone outcrops. Very low Se concentrations are present over the marine alluvium of the coastal strip and the Fens, although natural stream coverage is poor in the latter area. In stream sediments and soils of the east Midlands (Fig. 1(d,e)) high Se levels are prominent at sites over river alluvium in the Dove, Derwent and Trent valleys. These high levels are almost certainly a result of material derived from the Black Shale lithology of the Widmerpool Formation and the hydrothermal sulfide mineralisation of the Peak District. Low Se concentrations occur over Triassic terrain generally, especially to the south of Birmingham and Coventry, with higher concentrations over the lower and middle Jurassic terrain. Elsewhere, high Se concentrations around Birmingham are likely to be industrial in origin, whilst a prominent high-Se feature extending from the north of Grantham to the south of Peterborough may be associated with peat deposits. High $\mathrm{Se}$ concentrations in the 
(a)





Frequency distribution

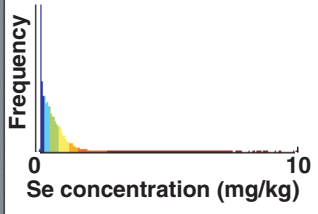

(b)
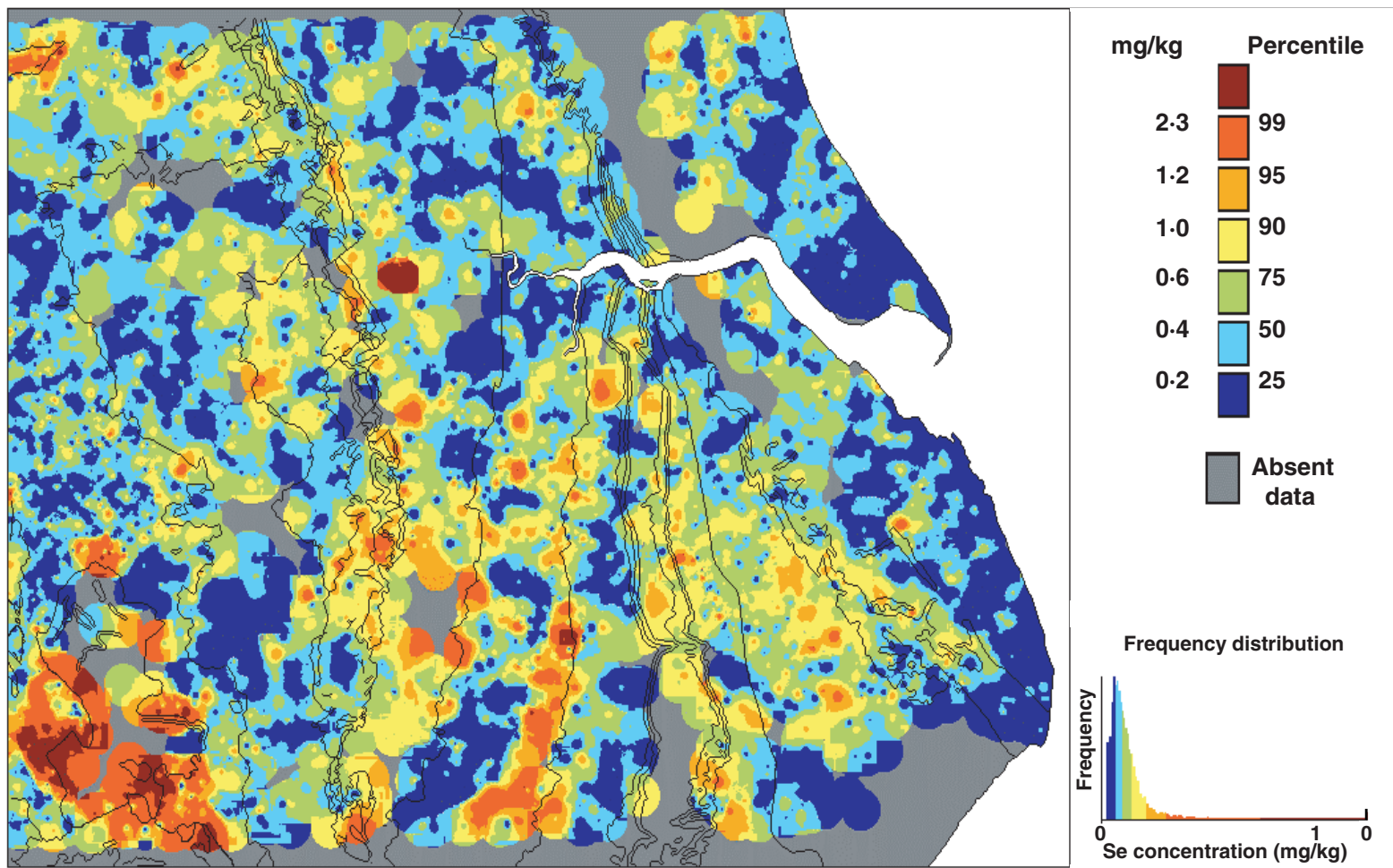

Fig. 1. (Cont.) 
(c)
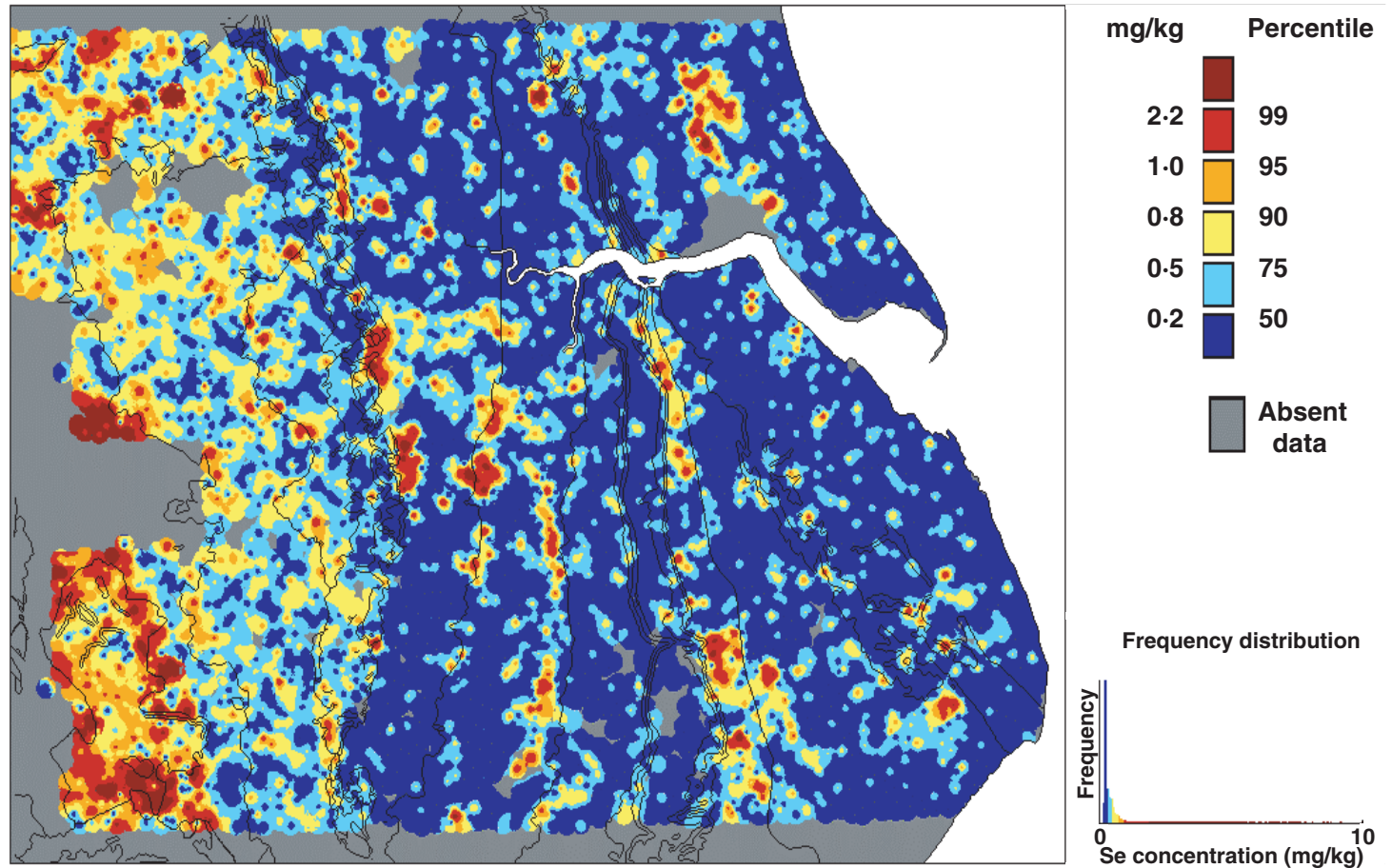

(d)
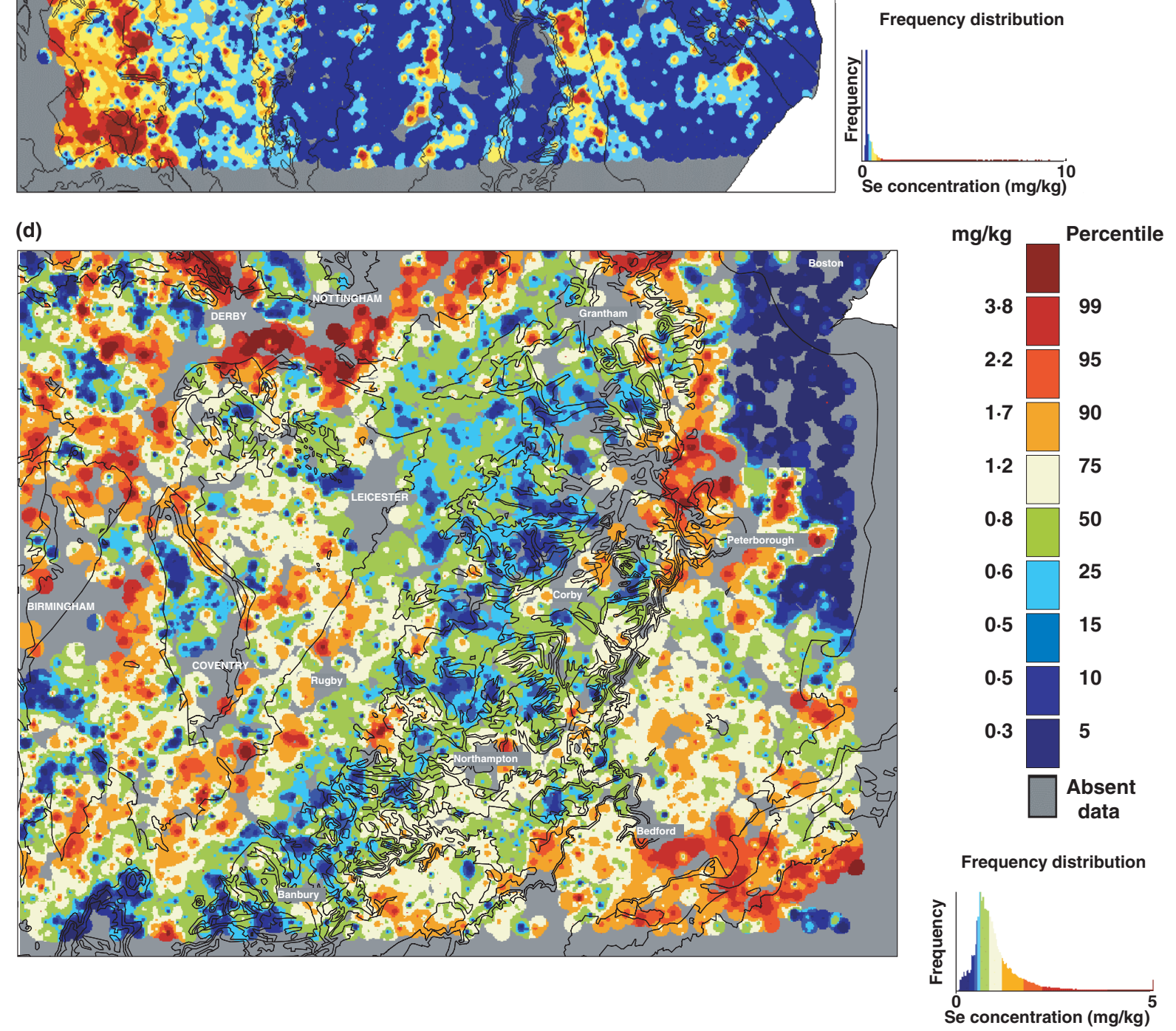

Fig. 1. (Cont.) 
(e)
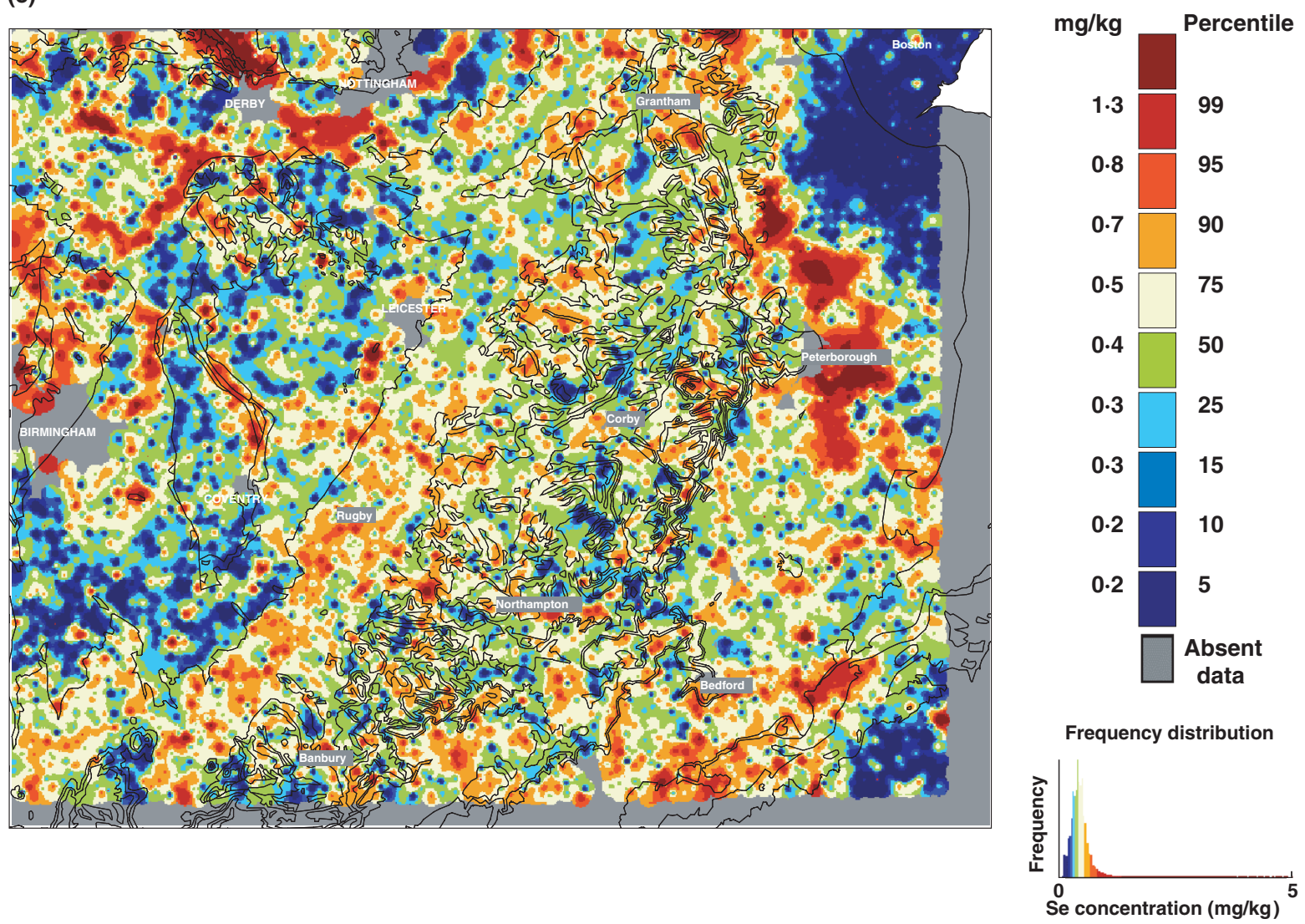

Fig. 1. Baseline selenium concentrations in UK drainage sediments in streams, water samples and soils from the Geochemical Baseline Survey of the Environment of the British Geological Survey (BGS; Johnson \& Breward, 2004). Soils and/or stream sediments were sampled at a density of one to two samples per $\mathrm{km}^{2}$ in Wales and in the Midlands of England. Samples of stream sediments were analysed for selenium in Wales and the west Midlands of England (a), whilst in the Humber-Trent drainage basin and in the east Midlands of England, stream sediments ( $b$ and $d$ respectively) and soils ( $c$ and e respectively) were analysed. (Data are reproduced with permission of BGS.)

south-east of the map may be associated with the Bedfordshire brick industry, but this association is not yet certain (Fig. 1(e)).

\section{Uptake, assimilation and accumulation of selenium by plants}

Se has no proven function in plant nutrition. However, plants take up Se from the soil solution primarily as selenate, and to a much lesser extent as selenite. Selenate enters root cells through sulfate transporters in their plasma membranes (Terry et al. 2000; White et al. 2004). Sulfate transporters are encoded by a small family of genes in most plant species; these transporters are hydrophobic membrane proteins with twelve predicted membranespanning domains and few large extramembrane loops but, generally, with long $\mathrm{N}$ and $\mathrm{C}$ termini (Hawkesford, 2003, 2005). There are fourteen genes encoding sulfate transporters in the genome of Arabidopsis thaliana (L.) Heynh. and a similar number in groups of other plant species (Hawkesford, 2005). All sulfate transporters characterised to date can be placed into one of five groups based on their protein sequences (Hawkesford, 2003, 2005), with each group having distinct functional characteristics. Group 1 transporters, such as AtSultr1:1, AtSultr1:2 and AtSultr1:3, are high-affinity sulfate transporters (HAST) that are thought to catalyse most selenate influx to plant cells. Sulfate uptake is regulated by gene transcription (Hawkesford, 2005); AtSultr1:1 and AtSultr1:2 catalyse sulfate influx to Arabidopsis roots and their expression is induced by S starvation (Takahashi et al. 2000; Yoshimoto et al. 2002; Maruyama-Nakashita et al. 2003). The expression of these HAST also appears to correlate well with plant Se uptake. For example, plants lacking group 1 HAST have reduced selenate uptake (Shibagaki et al. 2002), whilst the overexpression of genes encoding group 1 HAST in transgenic plants increases Se uptake (Terry et al. 2000). Interestingly, although the expression of genes encoding HAST is generally reduced when a plant has sufficient $S$, increasing the selenate concentration in the rhizosphere of S-replete plants can increase shoot S concentrations (Bell et al. 1992; White et al. 2004). This phenomenon has been interpreted as the consequence of either selenate or Se metabolites de-repressing the expression of genes encoding HAST (Takahashi et al. 2000; 
White et al. 2004). Although several of the HAST will transport selenate, the molecular structure responsible for their anionic selectivity is not known.

Following uptake selenate is likely to be transported to the plastids, or may remain in the cytoplasm where it is assimilated via the $\mathrm{S}$ assimilation pathway (for reviews of Se assimilation in plants, see Terry et al. 2000; Ellis \& Salt, 2003; for a review of S assimilation see Hawkesford, 2005). Briefly, selenate is activated by ATP sulphurylase to form adenosine $5^{\prime}$-phosphoselenate, which is reduced to selenite in the presence of adenosine $5^{\prime}$-phosphosulfate reductase, and subsequently to selenide via a non-enzymic step in the presence of glutathione. Selenide is assimilated into Sec and further into selenomethionine. These selenoamino acids can be incorporated into proteins nonspecifically, which can cause toxicity to the plant. Selenoamino acids can also be methylated; for example, $\mathrm{Se}-\mathrm{methylSec}$ is a characteristic Se assimilation product within species in the genera Allium and Brassica, which includes numerous crop species of commercial importance including onions, leeks, garlic, oilseed rape and cabbages. Methylated selenoamino acids can be converted to methyl selenol (Lu et al. 1995; Ip et al. 2002) and ultimately to dimethylselenide and volatilised (Ellis \& Salt, 2003). Se assimilation impacts directly on shoot Se accumulation. This relationship is supported by the observations that: (1) overexpression of ATP sulphurylase and/or genes involved in glutathione synthesis in transgenic Brassica juncea (L.) Czern. results in increased shoot Se accumulation (Pilon-Smits et al. 1999; Bañuelos et al. 2005); (2) overexpression of a Sec methyltransferase gene, which methylates $\mathrm{Sec}$ to methylSec in Astragalus bisulcatus (Hook.) A. Gray results in increased Se accumulation in transgenic A. thaliana and B. juncea (LeDuc et al. 2004); (3) expression of a Sec lyase, which breaks down Sec in mice, in the cytoplasm or in chloroplasts results in increased shoot Se concentration in transgenic A. thaliana (Pilon et al. 2003).

Flowering plant (angiosperm) species differ in their ability to assimilate and accumulate Se (Rosenfeld \& Beath, 1964; Dhillon \& Dhillon, 2003; Ellis \& Salt, 2003; White et al. 2004). These species can be divided into three groups: non-accumulators; Se indicators; Se accumulators. Non-accumulator plants rarely contain $>100 \mu \mathrm{g} \mathrm{Se/g} \mathrm{DM,}$ Se-indicator plants can contain $\leq 1000 \mu \mathrm{g} \mathrm{Se} / \mathrm{g} \mathrm{DM}$ and Se-accumulator plants can contain $\leq 40000 \mu \mathrm{g} \mathrm{Se} / \mathrm{g} \mathrm{DM}$ when sampled from Se-rich environments, e.g. in areas of western USA where soils have been derived from seleniferous shale and sedimentary materials. Also, nonaccumulator plants have a lower Se:S in their shoot tissues than Se-accumulator plants (Bell et al. 1992; Feist \& Parker, 2001). Remarkably, there is often no correlation between the shoot Se and S concentrations of different plant species (or even genotypes of the same species) growing in the same environment (Feist \& Parker, 2001; White et al. 2004). This finding suggests that the transporters responsible for the uptake or translocation of Se are selective for either sulfate (in non-accumulator plants whose shoot Se:S is lower than that in the rhizosphere solution) or selenate (in Se-accumulator plants whose shoot $\mathrm{Se}: \mathrm{S}$ ratio is higher than that in the rhizosphere solution). A selective advantage associated with plant Se accumulation has been suggested, since increased Se concentration protects $B$. juncea against infection with Fusarium and Alternaria and against herbiovory by aphids and caterpillars but not snails (Hanson et al. 2003, 2004). Examples of Se hyperaccumulators include members of the Fabaceae (Astragalus bisulcatus, A. racemosus Pursh), Asteraceae (Aster occidentalis (Nutt.) Torr. \& A. Gray, Machaeranthera ramosa A. Nelson), and Brassicaceae (Stanleya pinnata (Pursh) Britton). In Se accumulators Se predominantly occurs as non-protein-amino acid forms, Se-methylSec, and in a conjugated form as $\gamma$-glutamylmethylSec, but also as selenocystathione, selenohomocysteine, $\gamma$-glutamyl-selenocystathione, methyl selenol and selenate (Pickering et al. 2000, 2003). Extreme Se accumulation (as high as $22 \mathrm{~g} / \mathrm{kg}$ DM) has been reported in the fruit of some species within the Lecythidaceae family. This neotropical family of trees comprises 325 species within ten genera (Morton et al. 1998), including the familiar edible Brazil nut (Bertholletia excelsa Humb. \& Bonpl.) and less-familiar edible nuts such as the Paradise nut (Lecythis zabucaja Aubl.). However, the ingestion of certain other Lecythis species, including Coco de Mono (L. ollaria Loefl.) and Sapucaia nut (L. elliptica Kunth), can induce acute selenosis in human subjects (KerdelVegas, 1966; Dickson, 1969), characterised by symptoms of hair and nail loss, alongside other dermatological, neurological and gastric disorders (Fordyce 2005). In $B$. excelsa the dominant form of $\mathrm{Se}$ is selenomethionine (Vonderheide et al. 2002; Kannamkumarath et al. 2005).

\section{Selenium is an essential element for man}

Se was identified as an essential element for mammals in the 1950s (Schwarz \& Foltz, 1957). There are approximately thirty mammalian selenoproteins, about half of which have been characterised (Rayman, 2002). These proteins include those with functional roles as antioxidants (e.g. glutathione peroxidase) and those that contribute to protein stability, transcription of mRNA and other biochemical functions. Given these functions it is not surprising that $\mathrm{Se}$ is important for human health, and $\mathrm{Se}$ deficiency in human subjects has been linked to a plethora of physiological disorders (Rayman, 2000, 2002; Jackson et al. 2004). For example, low Se status causes Keshan disease (a cardiomyopathy) and Kashin-Beck disease (an osteoarthritis disorder) in parts of China where dietary Se intakes are extremely low (Fordyce, 2005). As a result of its role as an antioxidant, low Se status has also been linked to CVD, pancreatitis, asthma and inflammatory response syndrome (Rayman, 2000, 2002). Further, there is evidence that low Se status impacts on immune system functioning, response to viral infection, female (e.g. reduced rates of miscarriage) and male (e.g. sperm development and function) fertility and thyroid functioning if Se and I status are both deficient (Rayman, 2002).

There is substantial evidence that $\mathrm{Se}$ is a potent anticarcinogen when it is present at levels above those required for the maximal expression of selenoproteins, i.e. well above those levels associated with incipient Se deficiency 
(Combs, 2005). Indeed, both organic and inorganic forms of Se consistently inhibit cell growth and stimulate programmed cell death in vitro, whilst there is supporting (albeit inconclusive) epidemiological evidence of inverse relationships between Se status and the incidence of cancer (Combs, 2005). For example, in a randomised clinical trial $200 \mu \mathrm{g} \mathrm{Se} / \mathrm{d}$ has been shown to reduce total cancer incidences by a factor of 0.63 and to reduce incidences of carcinomas of the prostate and colon-rectum by 0.51 and 0.46 respectively (Clark et al. 1996, 1998; Combs, 2005).

\section{Selenium intake and status have declined in the UK}

Individual Se intakes range from 3 to $7000 \mu \mathrm{g} \mathrm{Se} / \mathrm{d}$ worldwide, although most intakes are at the lower end of this distribution (Fordyce, 2005). Se intake in the UK has declined from $>60 \mu \mathrm{g} \mathrm{Se} / \mathrm{d}$ in 1974 to $29-39 \mu \mathrm{g} \mathrm{Se} / \mathrm{d}$ (for reviews, see Rayman, 1997, 2000, 2002, 2004). In several other EU countries Se intakes are less than half the UK reference nutrient intakes of 60 and $75 \mu \mathrm{g} \mathrm{Se} / \mathrm{d}$ for females and males respectively (Rayman, 2004). A concomitant decline in Se status based on analysis of blood and serum has been reported, and thus the UK population may be at risk from an increased prevalence of certain health disorders (Rayman, 1997, 2000, 2002, 2004). Cereals represent a major source of $\mathrm{Se}$ in most UK diets, and the decline in Se intake and status in the UK has been attributed to changes in the sourcing of the wheat used for flour production from grains that are high in Se concentration and grown on high-Se soils in North America to UKsourced wheat that has been grown on low-Se soils and has a low grain Se content. The use of UK wheat in grists has risen from $15 \%$ in the 1950 s to $>80 \%$ in 2005 (Lea, 2005).

The baseline Se concentration of wheat grain used in UK bread has been analysed in samples taken in 1982, 1992 and 1998 (Adams et al. 2002), and a minimal difference in mean grain Se concentration between these samples has been found $(0.025,0.033$ and $0.025 \mathrm{mg} \mathrm{Se} / \mathrm{kg}$ respectively, with interquartile ranges varying from 0.015 to $0.019 \mathrm{mg} \mathrm{Se} / \mathrm{kg}$ ). By comparison, mean values of 0.370 and $0.457 \mathrm{mg} \mathrm{Se} / \mathrm{kg}$ have been reported for US wheat grain and $0.760 \mathrm{mg} \mathrm{Se} / \mathrm{kg}$ for Canadian grain (Adams et al. 2002). Worldwide, the Se content of wheat grain ranges from 0.001 to $30 \mathrm{mg} / \mathrm{kg}$, being predominantly within the range $0 \cdot 020-0.600 \mathrm{mg} \mathrm{Se} / \mathrm{kg}$ (Lyons et al. 2005a). It is important to emphasise that the primary reason for higher concentrations of Se in US and Canadian wheat grain than in wheat grain from the UK is a result of differences in the underlying geology and consequent higher Se concentrations in the North American soils. It is less related to differences in historical or current agronomic practices or to soil nutrient depletion. Consistent with the hypothesis of a link between Se content of wheat and dietary Se intakes and status is the observation that in New Zealand Se intakes and status increased when Australian wheat containing higher levels of Se were imported (Watkinson, 1981; Thomson \& Robinson, 1996). In addition to changes in the sourcing of wheat grain, levels of Se in UK diets may also have declined in recent years because of changes in fertiliser practices (e.g. replacing single superphosphate with triple superphosphate; White et al. 2004), or dilution in the crop as a result of improved yields (Adams et al. 2002). Further, since Se and pyritic S concentrations are correlated in coal (Spears et al. 1999), declines in Se inputs may also be related to a decline in the intensity of coal combustion following the Clean Air Act of 1956 (Ministry of Housing and Local Government, 1956; Haygarth et al. 1993) and/or the use of low-S coal or desulphurisation combustion technologies.

\section{Biofortifying crops in the UK}

The decline in Se intake and status in the UK can be rectified by dietary diversification, mineral supplementation of human subjects or livestock, food fortification during processing or through crop biofortification (Rayman, 2002, 2004). Since foods such as Brazil nuts, offal and crab meat, which naturally contain high levels of Se, are not eaten in great quantities, the potential for dietary diversification to increase Se delivery in the UK is limited (Rayman, 2002). The use of high-Se-containing supplements, including yeast-based formulations, appears to be an effective and a safe option for human subjects (Rayman, 2004). However, supplements are relatively expensive and only a small proportion of the population are likely to take such personal intervention measures, particularly since recent EU legislation restricts the sale of such supplements. During flour processing in the UK statutory nutrients are currently added to flour using a pre-blend that contains $\mathrm{CaCO}_{3}, \mathrm{Fe}$, thiamin and nicotinamide. Although Se could be fortified through this route, alterations to this blend would require a change in legislation. There is also a food safety issue associated with storing concentrated Se compounds in a mill or a baking environment. The present review will therefore focus on the strategy of biofortification, defined as increasing the bioavailable concentrations of essential elements in edible portions of crop plants through the use of fertilisers (agronomic biofortification) or through crop selection or breeding (genetic biofortification; Graham et al. 2001; Bouis, 2003; Bouis et al. 2003; Lyons et al. 2003).

\section{Agronomic biofortification}

The potential for using Se-containing fertilisers to increase crop Se concentrations, and thus dietary Se intakes, in the UK has been proposed previously (Adams et al. 2002; Rayman, 2002; Arthur, 2003). Possible strategies for Se fertilisation in the UK based on data obtained from other parts of the world will be reviewed. Strategies based on fertilising both pasture or forage crops for consumption by livestock and crops intended for direct human consumption will be considered.

Biofortification of pastures or forages using Se fertilisers has been widely demonstrated (for reviews, see GisselNielsen, 1998; Gupta \& Gupta, 2002). The primary driver for supplying pastures or forages with increased Se has been to prevent disorders amongst grazing livestock. For example, the muscular dystrophy disorder, white muscle disease, is associated with low-Se-status soils, notably in 
Australia, New Zealand and parts of North America (Wichtel, 1998; Lee et al. 1999; Fordyce, 2005). In early studies it was demonstrated that $\mathrm{Na}_{2} \mathrm{SeO}_{4}$ or $\mathrm{K}_{2} \mathrm{SeO}_{4}$ is more available for immediate uptake by pasture crops than selenite (Gissel-Nielsen, 1998). However, in the years following Se application selenite or less-soluble forms of selenate (e.g. $\mathrm{BaSeO}_{4}$ ) were found to provide longerlasting effects. For example, in Australia the application of prilled Se fertilisers (i.e. a granulated compound form) to pastures grazed by sheep was shown to increase crop Se concentration and consequently whole-blood and plasma Se concentrations, thereby increasing wool yield and live weights (Whelan et al. 1994a,b). In these studies it was found that $3-5 \mathrm{~g} \mathrm{Se} / \mathrm{ha}$ per year supplied as Selcote ${ }^{\circledR}$ (comprising $10 \mathrm{~g} \mathrm{Se} / \mathrm{kg}$ as $\mathrm{Na}_{2} \mathrm{SeO}_{4}$ ) provides an adequate Se supply to sheep for 1 year, whilst $10 \mathrm{~g} \mathrm{Se} / \mathrm{ha}$ per year, supplied as slow-release Selcote Two Year $^{\circledR}(10 \mathrm{~g} \mathrm{Se} / \mathrm{kg}$ as $1: 1 \mathrm{Na}_{2} \mathrm{SeO}_{4}: \mathrm{BaSeO}_{4} ; 10 \mathrm{~g} \mathrm{Se} / \mathrm{kg}$ ), provides adequate cover for 3 years. In Canada it has been shown that Selcote Ultra ${ }^{\circledR}\left(10 \mathrm{~g} \mathrm{Se} / \mathrm{kg}\right.$ as $\left.1: 3 \mathrm{Na}_{2} \mathrm{SeO}_{4}: \mathrm{BaSeO}_{4}\right)$ increases Se uptake by lucerne (Medicago sativa L.; Gupta, 1995). Crop Se concentration is increased from 0.067 to 0.187 and 0.220 at 5 and $10 \mathrm{~g} \mathrm{Se} / \mathrm{ha}$ per year respectively in the first cut and in the first year after application. Similarly, Se concentration in the first cut of Italian ryegrass (Lolium multiflorum Lam.) is increased from 0.067 to 0.231 and 0.292 at 5 and $10 \mathrm{~g} \mathrm{Se} /$ ha per year respectively. In subsequent years crops grown on soils that have initially received $\mathrm{Se}$ fertilisation contain more $\mathrm{Se}$ than non-fertilised control crops.

Elsewhere, similar increases in the Se concentration of pasture and forage crops in response to applications of low levels of Se have been reported. For example, in Canada an increase in Se concentrations has been reported for red clover (Trifolium pratense L.), timothy (Phleum pratense L.) and Italian ryegrass (Gupta \& MacLeod, 1994). In the USA the Se concentration of bahia grass (Paspalum notatum Flügge) sprayed with Selcote Ultra ${ }^{\circledR}$ at $5 \mathrm{~g} \mathrm{Se} / \mathrm{ha}$ per year has been shown to increase, as has that of fescue (Festuca spp.) top-dressed at the same rate (Valle et al. 2002). In Ireland Se uptake by ryegrass (Lolium perenne L.) has been found to increase from 0.10 and $0.13 \mathrm{Se}$ $\mathrm{mg} \mathrm{Se} / \mathrm{kg}$ dry weight in control plots to 0.62 and $0.19 \mathrm{Se}$ $\mathrm{mg} \mathrm{Se} / \mathrm{kg}$ at first and second cuts respectively in response to $76 \mathrm{~g} \mathrm{Se}$ as $\mathrm{Na}_{2} \mathrm{SeO}_{3}$ /ha per year (Murphy \& Quirke, 1997). Numerous other studies have demonstrated the ease of increasing the $\mathrm{Se}$ concentrations of pasture or forage crops using small quantities of Se fertilisers applied directly to the soil or applied as foliar sprays (Peterson \& Butler, 1962; Davies \& Watkinson, 1966; Cary et al. 1967; Watkinson \& Davies, 1967; Cary \& Allaway, 1969, 1973; Gissel-Nielsen \& Bisbjerg, 1970; Gissel-Nielsen, 1977, 1984, 1986; Gupta \& Winter, 1981, 1989; Gupta et al. 1982; Watkinson, 1983; Gissel-Nielsen et al. 1984; Van Dorst \& Peterson, 1984; Yläranta, 1984c; Whelan, 1989; Coutts et al. 1990; Rimmer et al. 1990; Shand et al. 1992; Jukola et al. 1996; MacLeod et al. 1998; Gupta \& Gupta, 2002; Valle et al. 2002).

It is clearly possible to increase the Se concentration of pasture and forage crops by Se fertilisation, and commercial products are available for supplying low levels of Se. Selcote Ultra ${ }^{\circledR}$ (Nufarm NZ, Auckland, New Zealand) was first released in 1989-90 to replace previous formulations Selcote ${ }^{\circledR}$ and Selcote Two Year ${ }^{\circledR}$, which were released in the early 1980s (M Shirer (AgBioResearch Ltd, Richmond, New Zealand), personal communication; there have been several changes in the ownership of Selcote ${ }^{\circledR}$ products, and companies cited in scientific publications include Lime and Marble Ltd, Agtech Developments Ltd, ICI Rural Division, ICI Crop Care, Crop Care, Nufarm NZ and AgBioResearch Ltd, which has been an international distributor of Selcote Ultra ${ }^{\circledR}$ since the late 1990s). In New Zealand Se can be applied to a maximum of $10 \mathrm{~g} \mathrm{Se} /$ ha per year (M Shirer, personal communication). In 1999 Top Stock ${ }^{\circledR}$ (Yara UK, Immingham, Lincs., UK), containing $0 \cdot 012 \mathrm{~g} \mathrm{Se} / \mathrm{kg}$, was released to the UK market. Recommended application rates for Top Stock ${ }^{\circledR}$ are $6.6 \mathrm{~g} \mathrm{Se} / \mathrm{ha}$, and $>25000$ ha grassland in the UK are currently treated with this product.

Biofortification of food crops for human consumption is a more direct strategy to increase dietary Se intake (GisselNielsen, 1998; Gupta \& Gupta, 2002). For example, the Se concentrations of wheat grain and flour can easily be raised by applying low concentrations of Se to soils (Eurola et al. 1989; Stephen et al. 1989; Singh, 1994; Lyons et al. 2003, 2004, 2005a,b). This strategy is also applicable to other cereal and grain crops (Gupta \& Gupta, 2002); for example, in field-grown rice the foliar application of $20 \mathrm{~g} \mathrm{Se} / \mathrm{ha}$ increases the Se concentrations of rice grain from a control level of 0.071 (SD 0.002) to 0.471 (SD 0.134) and 0.640 (SD 0.191) when Se is supplied as selenite and selenate respectively (Chen et al. 2002).

The best example of biofortification of food crops for human consumption using Se fertilisers comes from Finland. As a consequence of low dietary Se intakes the Finnish Ministry of Agriculture and Forestry decided in 1983 that Se would be incorporated into all multinutrient fertilisers used in agriculture from 1 July 1984 onwards (for reviews of the Finnish experience, including the primary literature sources for the Finnish Ministry directives, see Yläranta, 1984a,b,c; Varo et al. 1988; Eurola et al. 1989, 1991, 2004; Aro et al. 1995; Venäläinen et al. 1997; Rayman, 2002; see also references cited therein). The primary aim of the Finnish policy was a 10-fold increase in cereal-grain Se concentration (Venäläinen et al. 1997). For grain production and horticulture $16 \mathrm{mg} \mathrm{Se} / \mathrm{kg}$ was added to multinutrient fertiliser formulations, whilst for fodder crop and hay production $6 \mathrm{mg} \mathrm{Se} / \mathrm{kg}$ was added. However, since $>10$-fold increases in shoot Se concentration were reported in the years following initial Se applications, a new directive came into force from 16 June 1990 onwards, and fertilisers containing $16 \mathrm{mg} \mathrm{Se} / \mathrm{kg}$ were removed from the market and a single level of supplementation of $6 \mathrm{mg} \mathrm{Se} / \mathrm{kg}$ was used (Venäläinen et al. 1997). In $1998 \mathrm{Se}$ supplementation was increased from 6 to $10 \mathrm{mg} \mathrm{Se} / \mathrm{kg}$ fertiliser for all crops.

The effect of adding Se to fertilisers for crops in Finland has been marked; for example, Se concentrations have increased in 125 indigenous food items (Eurola et al. 1991). Notably, the Se concentration of wheat bran has increased 10 -fold from 0.03 to $0.35 \mathrm{mg} \mathrm{Se} / \mathrm{kg} \mathrm{DM}$. The Se content of all fruit and vegetables was $<0.01 \mathrm{mg} \mathrm{Se} / \mathrm{kg} \mathrm{DM}$ 
before Se supplementation (except lettuce (Lactuca sativa L.) and spinach (Spinacia oleracea L.), for which Se contents were 0.01 and $0.02 \mathrm{mg} / \mathrm{kg} \mathrm{DM}$ respectively; Eurola et al. 1989). After Se fertilisation $\geq 10$-fold (and $\leq 100$ fold) increases in the Se concentration of vegetable and fruit crops were reported (Eurola et al. 1989). Although the Se concentration of all crops has increased, more subtle effects have also been noted. For example, Se fertilisation has increased the Se concentration of oats (Avena sativa L.; Eurola et al. 2004). Not surprisingly, the grain Se concentration is greater in crops supplied with fertilisers incorporating Se at $10 \mathrm{mg} / \mathrm{kg}$ than at $6 \mathrm{mg} / \mathrm{kg}$, and it is lower in grain from organic production systems in which no fertilisers have been added. The Se concentration of oat grain is higher in seasons of low precipitation, and cultivar differences have been detected in variety trials. The Se concentrations of meat, meat products, fish, dairy products and processed foods have all increased following the introduction of Se fertilisation (Eurola et al. 1991); for example, for pig muscle meat and liver the Se concentrations were found to have increased from 0.08 and $0.49 \mathrm{mg} / \mathrm{kg}$ respectively in 1985 to a peak of 0.30 and $0.73 \mathrm{mg} / \mathrm{kg}$ respectively in 1989 (Venäläinen et al. 1997). Similarly, the Se concentrations for cattle muscle and liver increased from 0.07 and $0.28 \mathrm{mg} / \mathrm{kg}$ respectively in 1985 to 0.21 and $0.51 \mathrm{mg} / \mathrm{kg}$ respectively in 1989 .

Based on average Finnish diets, it has been reported (Eurola et al. 1991) that there was an increase in Se intake from $25 \mu \mathrm{g} / \mathrm{d}$ per capita in $1975-6$ to $124 \mu \mathrm{g} / \mathrm{d}$ per capita in 1989, and an increase in the consumption of Se from all foodstuffs. Notably, for cereals the increase in Se consumption was from 9 to $30 \mu \mathrm{g} / \mathrm{d}$ per capita between 1975-6 and 1989. Over the same period the increase in the Se consumption ( $\mu \mathrm{g} / \mathrm{d}$ per capita) was from 0.4 to 4 for vegetables and fruit, from $7 \cdot 7$ to 45 for meat, from $7 \cdot 9$ to 12 for fish and from $5 \cdot 4$ to 32 for dairy products and eggs (Eurola et al. 1991). Furthermore, a concomitant increase in blood (Varo et al. 1988) and serum (Wang et al. 1998) Se concentrations has been reported. For example, for Finnish children aged $<15$ years of age, the increase in mean serum Se was from 0.87 (range 0.54-1.44) $\mu \mathrm{mol} / \mathrm{l}$ in 1985 to 1.26 (range $0.96-1 \cdot 57$ ) $\mu \mathrm{mol} / 1$ in 1986 (Wang et al. 1998). Similarly, in adults, serum Se increased from 1.04 (range $0.62-1.35$ ) $\mu \mathrm{mol} / \mathrm{l}$ in 1985 to 1.30 (range $0 \cdot 87-1.72) \mu \mathrm{mol} / 1$ in 1986. These increases have been subsequently maintained. Increases in the Se status of Finnish human milk between 1987 and 1995 have also been noted (Kantola \& Vartiainen, 2001). Thus, the use of Se fertilisers in Finland has increased the crop Se content, increased dietary Se intakes and increased the Se status of the Finnish population (Rayman, 2002).

\section{Genetic biofortification}

Although it may be possible to increase the consumption of crop species that are genetically predisposed to accumulate more Se, dietary diversification is not always feasible (Rayman, 2002). However, within-species genetic variation could be used to increase the delivery of Se to human diets, i.e. through genetic biofortification (Lyons et al.
2004). In the first instance, it may be possible to simply select existing varieties of crops that accumulate more Se. In the longer term, it may be possible to breed crops for increased Se concentration.

There are few data on varietal differences in Se accumulation for most crop species. However, in the most detailed study reported to date Lyons et al. (2005a) have surveyed grain Se concentrations in commercial and advanced breeding lines of wheat, in ancestral diploid (Aegilops tauschii (Coss.) Schmal.) and durum wheats (Triticum dicoccum (Schrank) Schubl.) and their progeny, in wheat landrace accessions, in wheat recombinant inbred and doubled haploid mapping populations and in other cereal grains from barley (Hordeum vulgare L.), triticale (X Triticosecale Wittmack ex A. Camus.) and rye (Secale cereale L.). Grain Se concentrations vary from 0.005 to $0.720 \mathrm{mg} \mathrm{Se} / \mathrm{kg}$, although most of the variation in grain Se from these species is attributed to soil factors. However, A. tauschlii accumulates most $\mathrm{Se}$ in the grain and there is therefore the potential to breed for increased grain $\mathrm{Se}$ concentration in wheat (Lyons et al. 2005a).

In other crops, 4-fold differences in shoot Se accumulation between four Lycopersicon cultivars (tomatoes and relatives) grown at low sulfate levels have been reported (Pezzarossa et al. 1999). Differences in short-term net Se uptake and shoot Se concentration have also been noted amongst eight Lycopersicon esculentum L. cultivars and six other Lycopersicon species, with greater variation in shoot Se concentration between wild Lycopersicon taxa than between cultivated Lycopersicon taxa (Shennan et al. 1990). Variation in Se accumulation has also been reported for soyabean (Glycine $\max$ (L.) Merr.; Yang et al. 2003; Zhang et al. 2003) and onion (Allium cepa L.; Kopsell \& Randle, 1997), whilst Se accumulation in rapid-cycling Brassica oleracea L. has been shown to be moderately heritable, with expected gains of $5 \%$ per cycle of recurrent selection (Kopsell \& Randle, 2001).

In non-crop species shoot Se concentrations have been found to vary amongst sixteen populations of Stanleya pinnata by $1 \cdot 4$-fold-3.6-fold and shoot Se concentrations correlate with the Se concentration of the soil from which the populations were originally collected (Feist \& Parker, 2001).

For a given crop species, if sufficient genetic variation exists in Se accumulation, and if this variation is heritable, traditional breeding programmes could be developed that would provide an alternative to agronomic biofortification and thus minimise the need to use Se fertilisers except at the lowest soil Se concentrations (Lyons et al. 2004, 2005a).

In addition to identifying suitable germplasm for breeding, accelerated breeding strategies to increase Se concentration in crops may also be possible. For example, Se accumulation can be quantified in different accessions of model crop or non-crop plant species for which genetic maps are available. Inbred progeny from crosses between these two accessions can then be used to map Se accumulation to specific chromosomal loci, i.e. quantitative trait loci analyses (Vreugdenhil et al. 2005; Wissuwa, 2005). Following the identification of quantitative trait loci impacting on shoot Se accumulation, for example, candidate 
genes or loci could be resolved through fine mapping, and sequence information could be used directly, for genebased selection or marker-assisted breeding. An advantage of this strategy is that knowledge of the genes and/or chromosomal loci controlling Se accumulation in one plant species could be used in a different target crop species. It is also possible to devise breeding or selection strategies (conventional or through genetic modification) for increasing shoot $\mathrm{Se}$ concentration based on existing knowledge of Se (and S) uptake and assimilation. For example, overexpressing ATP sulphurylase and/or genes involved in glutathione synthesis increases shoot $\mathrm{Se}$ accumulation in transgenic B. juncea (Pilon-Smits et al. 1999; Bañuelos et al. 2005), whilst overexpressing a Sec methyltransferase gene that methylates $\mathrm{Sec}$ to methylSec in A. bisulcatus increases $\mathrm{Se}$ accumulation in transgenic A. thaliana and B. juncea (LeDuc et al. 2004).

\section{Perspective}

Se intake and status in the UK population can be increased in the short term through agronomic biofortification. The pasture and forage sector already uses commercial Se fertilisers and an increased usage in this sector could increase dietary Se intakes through meat and dairy products. However, in order to provide adequate quantities and forms of Se for the widest possible number in the population Se fertilisation of crops for direct human consumption is likely to be needed. Such a strategy has been adopted in Finland, and there is substantial evidence to demonstrate that this strategy is biologically safe and environmentally acceptable (Wang et al. 1994; 1995; Mäkelä et al. 1995). From a crop perspective, antagonistic and synergistic interactions between Se and $\mathrm{S}$ will occur during plant uptake that may affect crop quality (White et al. 2004). These interactions will depend on the prevailing relative concentration of each of the elements in the soil. However, at low external $\mathrm{S}$, and under low rainfall conditions, $\mathrm{Se}$ fertiliser application rates of $\leq 200 \mathrm{~g} \mathrm{Se} /$ ha have not been found to induce toxic effects or to retard growth in a lowyielding wheat crop (Lyons et al. 2005b).

In cereals selenomethionine is the dominant organic form of Se. Wheat is the most efficient accumulator of Se within the common cereal crops (wheat $>$ rice $>$ maize $>$ barley>oats) and it is one of the most important Se sources for human subjects in the UK (Lyons et al. 2003). Thus, wheat is an obvious target crop for agronomic biofortification to increase the dietary Se intake, and thus the Se status, of the UK population. Currently, the average Se level in the grain of UK wheat is $25-33 \mu \mathrm{g} \mathrm{Se} / \mathrm{kg}$ (Adams et al. 2002). Since the application of $10 \mathrm{~g} \mathrm{Se} / \mathrm{ha}$ applied as $\mathrm{Na}_{2} \mathrm{SeO}_{4}$ to the soil or as a foliar feed is likely to increase grain concentrations by 10 -fold, a Se-fertilisation strategy to rectify dietary Se deficiency for large sections of the population would require only a small addition of $\mathrm{Se}$ through fertilisation. In contrast, vegetables and fruit deliver small proportions of minerals to the diet (White \& Broadley, 2005). Thus, altering Se concentrations of these crops will have a minimal effect on dietary Se intakes. However, some vegetables contain organic forms of Se that make them attractive complimentary targets for biofortification. For example, Se-methylSec occurring in Allium and Brassica crops can be converted directly into methyl selenol, a bioactive substance that may protect against cancer (Lu et al. 1995; Ip et al. 2002; Whanger, 2004).

In addition to providing adequate quantities and forms of Se, an effective fertilisation strategy must be demonstrably safe to the environment. Although $>95 \% \mathrm{UK}$ soils for which geochemical data are available contain $<1.0 \mu \mathrm{g} \mathrm{Se} / \mathrm{g}$, elevated soil Se levels are associated with restricted geological, alluvial and industrial features (Fig. 1) and thus Se-fertilisation strategies must be devised and monitored appropriately. In the UK the quality and quantity of baseline geochemical data for soils, stream sediments and surface waters will enable such monitoring to be undertaken with confidence. However, total Se concentration in soil does not necessarily indicate its bioavailability, and thus factors influencing Se bioavailability must also be considered. In the longer term, it may be possible to exploit genotypic variation in Se accumulation in crops to select or breed varieties with increased Se (Lyons et al. 2004, 2005a), thereby minimising the need to use Se fertilisers in all but the lowest soil Se situations. This strategy may have economic advantages over a strategy based entirely on fertilisation.

\section{Acknowledgements}

Authors from the Universities of Nottingham and Warwick acknowledge financial support from the Biotechnology and Biological Sciences Research Council (BBSRC) of the UK and Yara (UK). Rothamsted Research receives grant-aided support from the BBSRC.

\section{References}

Adams ML, Lombi E, Zhao F-J \& McGrath SP (2002) Evidence of low selenium concentrations in UK bread-making wheat grain. Journal of the Science of Food and Agriculture 82, $1160-1165$.

Aro A, Alfthan G \& Varo P (1995) Effects of supplementation of fertilizers on human selenium status in Finland. Analyst 120, 841-843.

Arthur JR (2003) Selenium supplementation: does soil supplementation help and why? Proceedings of the Nutrition Society 62, 393-397.

Bañuelos G, Terry N, LeDuc DL, Pilon-Smits EAH \& Mackey B (2005) Field trial of transgenic Indian mustard plants shows enhanced phytoremediation of selenium-contaminated sediment. Environmental Science and Technology 39, 1771-1777.

Bell PF, Parker DR \& Page AL (1992) Contrasting selenatesulfate interactions in selenium-accumulating and nonaccumulating plant species. Soil Science Society of America Journal 56, 1818-1824.

Bouis HE (2003) Micronutrient fortification of plants through plant breeding: can it improve nutrition in man at low cost? Proceedings of the Nutrition Society 62, 403-411.

Bouis HE, Chassy BM \& Ochanda JO (2003) Genetically modified food crops and their contribution to human nutrition and food quality. Trends in Food Science and Technology 14, 191-209.

Brookins DG (1987) Eh-pH Diagrams for Geochemistry. New York: Springer-Verlag. 
Cary EE \& Allaway WH (1969) Stability of different forms of selenium applied to low-selenium soils. Soil Science Society of America Proceedings 33, 571-574.

Cary EE \& Allaway WH (1973) Selenium content of field crops grown on selenite-treated soils. Agronomy Journal 65, 922-925.

Cary EE, Wieczorek GA \& Allaway WH (1967) Reactions of selenite-selenium added to soils that produce low-selenium forages. Soil Science Society of America Proceedings 31, 21-26.

Castellano S, Novoselov SV, Kryukov GV, Lescure A, Blanco E, Krol A, Gladyshev VN \& Guigó R (2004) Reconsidering the evolution of eukaryotic selenoproteins: a novel nonmammalian family with scattered phylogenetic distribution. EMBO Reports 5, 71-77.

Chen L, Yang F, Xu J, Hu Y, Hu Q, Zhang Y \& Pan G (2002) Determination of selenium concentration of rice in China and effect of fertilization of selenite and selenate on selenium content of rice. Journal of Agricultural and Food Chemistry 50, 5128-5130.

Clark LC, Combs GF Jr, Turnbull BW, Slate E, Alberts D, Abele $\mathrm{D}$ et al. (1996) The nutritional prevention of cancer with selenium 1983-1993: a randomized clinical trial. Journal of the American Medical Association 276, 1957-1963.

Clark LC, Dalkin B, Krongrad A, Combs GF Jr, Turnbull BW, Slate EH et al. (1998) Decreased incidence of prostate cancer with selenium supplementation: results of a double-blind cancer prevention trial. British Journal of Urology 81, 730-734.

Combs GF (2005) Current evidence and research needs to support a health claim for selenium and cancer prevention. Journal of Nutrition 135, 343-347.

Coutts G, Atkinson D \& Cooke S (1990) Application of selenium prills to improve the selenium supply to a grass clover sward. Communications in Soil Science and Plant Analysis 21, 951-963.

Davies EB \& Watkinson JH (1966) Uptake of native and applied selenium by pasture species I. Uptake of Se by browntop, ryegrass, cocksfoot, and white clover from Atiamuri sand. New Zealand Journal of Agricultural Research 9, 317-327.

De Gregori I, Lobos MG \& Pinochet H (2002) Selenium and its redox speciation in rainwater from sites of Valparaiso region in Chile, impacted by mining activities of copper ores. Water Research 36, 115-122.

Dhillon KS \& Dhillon SK (2003) Distribution and management of seleniferous soils. Advances in Agronomy 79, 119-184.

Dickson JD (1969) Notes on hair and nail loss after ingesting Sapucaia Nuts (Lecythis elliptica). Economic Botany 23, 133-134.

Driscoll DM \& Copeland PR (2003) Mechanism and regulation of selenoprotein synthesis. Annual Review of Nutrition 23, $17-40$.

Ellis DR \& Salt DE (2003) Plants, selenium and human health. Current Opinion in Plant Biology 6, 273-279.

Elrashidi MA, Adriano DC \& Lindsay WL (1989) Solubility, speciation and transformation of selenium in soils. In Selenium in Agriculture and the Environment. Soil Science Society of America Special Publication no. 23, pp. 51-63 [LW Jacobs, editor]. Madison, WI: SSSA.

Elrashidi MA, Adriano DC, Workman SM \& Lindsay WL (1987) Chemical-equilibria of selenium in soils - a theoretical development. Soil Science 144, 141-152.

Eurola M, Ekholm P, Ylinen M, Koivistoinen P \& Varo P (1989) Effects of selenium fertilization on the selenium content of selected Finnish fruits and vegetables. Acta Agriculturae Scandinavica 39, 345-350.
Eurola M, Hietaniemi V, Kontturi M, Tuuri H, Kangas A, Niskanen M \& Saastamoinen M (2004) Selenium content of Finnish oats in 1997-1999: effect of cultivars and cultivation techniques. Agricultural and Food Science 13, 46-53.

Eurola MH, Ekholm PI, Ylinen ME, Koivistoinen PE \& Varo PT (1991) Selenium in Finnish foods after beginning the use of selenate supplemented fertilizers. Journal of the Science of Food and Agriculture 56, 57-70.

Feist LJ \& Parker DR (2001) Ecotypic variation in selenium accumulation among populations of Stanleya pinnata. New Phytologist 149, 61-69.

Fordyce F (2005) Selenium deficiency and toxicity in the environment. In Essentials of Medical Geology, pp. 373-415 [O Selinus, B Alloway, J Centeno, R Finkelman, R Fuge, U Lindh and P Smedley, editors]. London: Elsevier.

Gissel-Nielsen G (1977) Control of selenium in plants. Risø Report no. 370, pp. 1-42. Roskilde, Denmark: Ris $\varnothing$ National Laboratory.

Gissel-Nielsen G (1984) Improvement of selenium status of pasture crops. Biological Trace Element Research 6, 281-288.

Gissel-Nielsen G (1986) Comparison of selenium treatments of crops in the field. Biological Trace Element Research 10, 209-213.

Gissel-Nielsen G (1998) Effects of selenium supplementation of field crops. In Environmental Chemistry of Selenium, pp. 99-112 [WT Frankenberger and RA Engberg, editors]. New York: Dekker.

Gissel-Nielsen G \& Bisbjerg B (1970) The uptake of applied selenium by agricultural plants. 2. The utilization of various selenium compounds. Plant and Soil 32, 382-396.

Gissel-Nielsen G, Gupta UC, Lamand M \& Westermarck T (1984) Selenium in soils and plants and its importance in livestock and human nutrition. Advances in Agronomy 37, 397-460.

Gondi F, Panto G, Feher J, Bogye G \& Alfthan G (1992) Selenium in Hungary - the rock-soil-human system. Biological Trace Element Research 35, 299-306.

Graham RD, Welch RM \& Bouis HE (2001) Addressing micronutrient malnutrition through enhancing the nutritional quality of staple foods: principles, perspectives and knowledge gaps. Advances in Agronomy 70, 77-142.

Gupta UC (1995) Effects of Selcote ${ }^{\circledR}$ Ultra and sodium selenate (laboratory versus commercial grade) on selenium concentration in feed crops. Journal of Plant Nutrition 18, 16291636.

Gupta UC \& Gupta SC (2002) Quality of animal and human life as affected by selenium management of soils and crops. Communications in Soil Science and Plant Analysis 33, 15-18.

Gupta UC \& MacLeod JA (1994) Effect of various sources of selenium fertilization on the selenium concentration of feed crops. Canadian Journal of Soil Science 74, 285-290.

Gupta UC, McRae KB \& Winter KA (1982) Effect of applied selenium on the selenium content of barley and forages and soil selenium depletion rates. Canadian Journal of Soil Science 62, 145-154.

Gupta UC \& Winter KA (1981) Long-term residual effects of applied selenium on the selenium uptake by plants. Journal of Plant Nutrition 3, 493-502.

Gupta UC \& Winter KA (1989) Effect of selenate vs selenite forms of selenium in increasing the selenium concentration in forages and cereals. Canadian Journal of Soil Science 69, 885-889.

Hanson B, Garifullina GF, Lindblom SD, Wangeline A, Ackley A, Kramer K, Norton AP, Lawrence CB \& Pilon-Smits EAH (2003) Selenium accumulation protects Brassica juncea from invertebrate herbivory and fungal infection. New Phytologist 159, 461-469. 
Hanson B, Lindblom SD, Loeffler ML \& Pilon-Smits EAH (2004) Selenium protects plants from phloem-feeding aphids due to both deterrence and toxicity. New Phytologist 162, 655-662.

Hawkesford MJ (2003) Transporter gene families in plants: the sulphate transporter gene family-redundancy or specialization? Physiologia Plantarum 117, 155-165.

Hawkesford MJ (2005) Sulphur. In Plant Nutritional Genomics, pp. 87-111 [MR Broadley and PJ White, editors]. Oxford: Blackwell.

Haygarth PM, Cooke AI, Jones KC, Harrison AF \& Johnston AE (1993) Long-term change in the biogeochemical cycling of atmospheric selenium: deposition to plants and soil. Journal of Geophysical Research 98, 16769-16776.

Ip C, Dong Y \& Ganther HE (2002) New concepts in selenium chemoprevention. Cancer and Metastasis Reviews 21, 281-289.

Jackson MJ, Dillon SA, Broome CS, McArdle A, Hart CA \& McArdle F (2004) Are there functional consequences of a reduction in selenium intake in UK subjects? Proceedings of the Nutrition Society 63, 513-517.

Johnson CC \& Breward N (2004) G-BASE Geochemical Baseline Survey of the Environment. Commissioned Report CR/04/ 016N. Keyworth, Notts.: British Geological Survey.

Jukola E, Hakkarainen J, Saloniemi H \& Sankari S (1996) Effect of selenium fertilization on selenium in feedstuffs and selenium, vitamin $\mathrm{E}$, and $\beta$-carotene concentrations in blood of cattle. Journal of Dairy Science 79, 831-837.

Kannamkumarath SS, Wrobel K \& Wuilloud RG (2005) Studying the distribution pattern of selenium in nut proteins with information obtained from SEC-UV-ICP-MS and CE-ICP-MS Talanta 66, 153-159.

Kantola M \& Vartiainen T (2001) Changes in selenium, zinc, copper and cadmium contents in human milk during the time when selenium has been supplemented to fertilizers in Finland. Journal of Trace Elements in Medicine and Biology 15, 11-17.

Kerdel-Vegas F (1966) The depilatory and cytotoxic actions of 'Coco de Mono' (Lecythis ollaria) and its relationship to chronic selenosis. Economic Botany 23, 133-134.

Kopsell DA \& Randle WM (1997) Short-day onion cultivars differ in bulb selenium and sulfur accumulation which can affect bulb pungency. Euphytica 96, 385-390.

Kopsell DA \& Randle WM (2001) Genetic variances and selection potential for selenium accumulation in a rapid-cycling Brassica oleracea population. Journal of the American Society for Horticultural Science 126, 329-335.

Lea A (2005) A fresh look at bread. Arable Farming 32, Issue no. 9, 6 June, 14

LeDuc DL, Tarun AS, Montes-Bayon M, Meija J, Malit MF, Wu CP et al. (2004) Overexpression of selenocysteine methyltransferase in Arabidopsis and Indian mustard increases selenium tolerance and accumulation. Plant Physiology 135, 377-383.

Lee J, Masters DG, White CL, Grace ND \& Judson GJ (1999) Current issues in trace element nutrition of grazing livestock in Australia and New Zealand. Australian Journal of Agricultural Research 50, 1341-1364.

Lu JX, Jiang C, Kaeck M, Ganther H, Vadhanavikit S, Ip C \& Thompson H (1995) Dissociation of the genotoxic and growthinhibitory effects of selenium. Biochemical Pharmacology 50, 213-219.

Lyons G, Ortiz-Monasterio I, Stangoulis J \& Graham R (2005a) Selenium concentration in wheat grain: Is there sufficient genotypic variation to use in breeding? Plant and Soil 269, 269-380.

Lyons G, Stangoulis J \& Graham R (2003) High-selenium wheat: biofortification for better health. Nutrition Research Reviews 16, 45-60.
Lyons GH, Stangoulis JCR \& Graham RD (2004) Exploiting micronutrient interaction to optimize biofortification programs: The case for inclusion of selenium and iodine in the HarvestPlus program. Nutrition Reviews 62, 247-252.

Lyons GH, Stangoulis JCR \& Graham RD (2005b) Tolerance of wheat (Triticum aestivum L.) to high soil and solution selenium levels. Plant and Soil 270, 179-188.

MacLeod JA, Gupta UC, Milburn P \& Sanderson JB (1998) Selenium concentration in plant material, drainage and surface water as influenced by Se applied to barley foliage in a barleyred clover-potato rotation. Canadian Journal of Soil Science 78, 685-688.

Mäkelä A, Wan Wang W-C, Hamalainen M, Nanto V, Laihonen P, Kotilainen H, Meng LX \& Mäkelä P (1995) Environmental effects of nationwide selenium fertilization in Finland. Biological Trace Element Research 47, 289-298.

Maruyama-Nakashita A, Inoue E, Watanabe-Takahashi A, Yamaya T \& Takahashi H (2003) Transcriptome profiling of sulfur-responsive genes in Arabidopsis reveals global effects of sulfur nutrition on multiple metabolic pathways. Plant Physiology 132, 597-605.

Ministry of Housing and Local Government (1956) Clean Air Act, 1956 - Smoke Control Areas. London: H. M. Stationery Office.

Morton CM, Prance GT, Mori SA \& Thorburn LG (1998) Recircumscription of the Lecythidaceae. Taxon 47, 817-827.

Murphy MD \& Quirke WA (1997) The effect of sulphur/ nitrogen/selenium interactions on herbage yield and quality. Irish Journal of Agricultural and Food Research 36, 31-38.

Peterson PJ \& Butler GW (1962) Uptake and assimilation of selenite by higher plants. Australian Journal of Biological Sciences 15, 126-146.

Pezzarossa B, Piccotino D, Shennan C \& Malorgio F (1999) Uptake and distribution of selenium in tomato plants as affected by genotype and sulphate supply. Journal of Plant Nutrition 22, 1613-1635.

Pickering IJ, Prince RC, Salt DE \& George GN (2000) Quantitative, chemically specific imaging of selenium transformation in plants. Proceedings of the National Academy of Sciences USA 97, 10717-10722.

Pickering IJ, Wright C, Bubner B, Ellis D, Persans MW, Yu EY, George GN, Prince RC \& Salt DE (2003) Chemical form and distribution of selenium and sulfur in the selenium hyperaccumulator Astragalus bisulcatus. Plant Physiology 131, 1460-1467.

Pilon M, Owen JD, Garifullina GF, Kurihara T, Mihara H, Esaki N \& Pilon-Smits EAH (2003) Enhanced selenium tolerance and accumulation in transgenic Arabidopsis expressing a mouse selenocysteine lyase. Plant Physiology 131, 1250-1257.

Pilon-Smits EAH, Hwang S, Lytle CM, Zhu Y, Tai JC, Bravo RC, Chen Y, Leustek T \& Terry N (1999) Overexpression of ATP sulfurylase in Indian mustard leads to increased selenate uptake, reduction, and tolerance. Plant Physiology 119, 123-132.

Rayman MP (1997) Dietary selenium: time to act. British Medical Journal 314, 387-388.

Rayman MP (2000) The importance of selenium to human health Lancet 356, 233-241.

Rayman MP (2002) The argument for increasing selenium intake. Proceedings of the Nutrition Society 61, 203-215.

Rayman MP (2004) The use of high-selenium yeast to raise selenium status: how does it measure up? British Journal of Nutrition 92, 557-573.

Rimmer DL, Shiel RS, Syers JK \& Wilkinson M (1990) Effects of soil application of selenium on pasture composition. Journal of the Science of Food and Agriculture 51, 407-410. 
Rosenfeld I \& Beath OA (1964) Selenium: Geobotany, Biochemistry, Toxicity, and Nutrition. New York: Academic Press.

Schwarz K \& Foltz CM (1957) Selenium as an integral part of factor-3 against dietary necrotic liver degeneration. Journal of the American Chemical Society 79, 3292-3293.

Shand C, Coutts G, Duff E \& Atkinson D (1992) Soil selenium treatments to ameliorate selenium deficiency in herbage. Journal of the Science of Food and Agriculture 59, 27-35.

Shennan C, Schachtman DP \& Cramer GR (1990) Variation in $\left.{ }^{75} \mathrm{Se}\right]$ selenate uptake and partitioning among tomato cultivars and wild species. New Phytologist 115, 523-530.

Shibagaki N, Rose A, McDermott JP, Fujiwara T, Hayashi H, Yoneyama T \& Davies JP (2002) Selenate-resistant mutants of Arabidopsis thaliana identify Sultrl;2, a sulfate transporter required for efficient transport of sulfate into roots. Plant Journal 29, 475-486.

Singh BR (1994) Effect of selenium-enriched calcium nitrate, top-dressed at different growth-stages, on the selenium concentration in wheat. Fertilizer Research 38, 199-203.

Spears DA, Manzanares-Papayanopoulos LI \& Booth CA (1999) The distribution and origin of trace elements in a UK coal; the importance of pyrite. Fuel 78, 1671-1677.

Stephen RC, Saville DJ \& Watkinson JH (1989) The effects of sodium selenate applications on growth and selenium concentration in wheat. New Zealand Journal of Crop and Horticultural Science 17, 229-237.

Takahashi H, Watanabe-Takahashi A, Smith FW, Blake-Kalff M, Hawkesford MJ \& Saito K (2000) The roles of three functional sulphate transporters involved in uptake and translocation of sulphate in Arabidopsis thaliana. Plant Journal 23, 171-182.

Terry N, Zayed AM, de Souza MP \& Tarun AS (2000) Selenium in higher plants. Annual Review of Plant Physiology and Plant Molecular Biology 51, 401-432.

Thomson CD \& Robinson MF (1996) The changing selenium status of New Zealand residents. European Journal of Clinical Nutrition 50, 107-114.

Valle G, McDowell LR, Prichard DL, Chenoweth PJ, Wright DL, Martin FG, Kunkle WE \& Wilkinson NS (2002) Selenium concentration of fescue and bahia grasses after applying a selenium fertilizer. Communications in Soil Science and Plant Analysis 33, 1461-1472.

van Dorst SH \& Peterson PJ (1984) Selenium speciation in the soil solution and its relevance to plant uptake. Journal of the Science of Food and Agriculture 35, 601-605.

Varo P, Alfthan G, Ekholm P, Aro A \& Koivistoinen P (1988) Selenium intake and serum selenium in Finland - effects of soil fertilization with selenium. American Journal of Clinical Nutrition 48, 324-329.

Venäläinen E-R, Hirvi T \& Hirn J (1997) Effect of selenium supplementation on the selenium content in muscle and liver of Finnish pigs and cattle. Journal of Agricultural and Food Chemistry 45, 810-813.

Vonderheide AP, Wrobel K, Kannamkumarath SS, B'Hymer C, Montes-Bayón M, de León CP \& Caruso JA (2002) Characterization of selenium species in Brazil nuts by HPLCICP-MS and ES-MS. Journal of Agricultural and Food Chemistry 50, 5722-5728.

Vreugdenhil D, Aarts MGM \& Koornneef M (2005) Exploring natural genetic variation to improve plant nutrient content. In Plant Nutritional Genomics, pp. 201-219 [MR Broadley and PJ White, editors]. Oxford: Blackwell.

Wang D, Alfthan G, Aro A, Lahermo P \& Väänänen P (1994) The impact of selenium fertilisation on the distribution of selenium in rivers in Finland. Agriculture, Ecosystems and Environment 50, 133-149.

Wang D, Alfthan G, Aro A, Mäkelä A, Knuuttila S \& Hammar T (1995) The impact of selenium supplemented fertilization on selenium in lake ecosystems in Finland. Agriculture, Ecosystems and Environment 54, 137-148.

Wang W-C, Mäkelä A-L, Näntö V, Mäkelä P \& Lagström $H$ (1998) The serum selenium concentrations in children and young adults: a long-term study during the Finnish selenium fertilization programme. European Journal of Clinical Nutrition 52, 529-535.

Watkinson JH (1981) Changes of blood selenium in New Zealand adults with time and importation of Australian wheat American Journal of Clinical Nutrition 34, 936-942.

Watkinson JH (1983) Prevention of selenium deficiency in grazing animals by annual topdressing of pasture with sodium selenate. New Zealand Veterinary Journal 31, 78-85.

Watkinson JH \& Davies EB (1967) Uptake of native and applied selenium by pasture species. 4 . Relative uptake through foliage and roots by white clover and browntop. Distribution of selenium in white clover. New Zealand Journal of Agricultural Research 10, 122-131.

Whanger PD (2004) Selenium and its relationship to cancer: an update. British Journal of Nutrition 91, 11-28.

Whelan BR (1989) Uptake of selenite fertilizer by subterranean clover pasture in Western Australia. Australian Journal of Experimental Agriculture 29, 517-522.

Whelan BR, Barrow NJ \& Peter DW (1994a) Selenium fertilizers for pastures grazed by sheep. 2. Wool and liveweight responses to selenium. Australian Journal of Agricultural Research 45 , 877-887.

Whelan BR, Peter DW \& Barrow NJ (1994b) Selenium fertilizers for pastures grazed by sheep. 1. Selenium concentrations in whole-blood and plasma. Australian Journal of Agricultural Research 45, 863-875.

White PJ, Bowen HC, Parmaguru P, Fritz M, Spracklen WP, Spiby RE et al. (2004) Interactions between selenium and sulphur nutrition in Arabidopsis thaliana. Journal of Experimental Botany 55, 1927-1937.

White PJ \& Broadley MR (2005) Historical variation in the mineral composition of edible horticultural products. Journal of Horticultural Science and Biotechnology 80, 660-667.

Wichtel JJ (1998) A review of selenium deficiency in grazing ruminants. part 1: New roles for selenium in ruminant metabolism. New Zealand Veterinary Journal 46, 47-52.

Wissuwa M (2005) Mapping nutritional traits in crop plants. In Plant Nutritional Genomics, pp. 220-241 [MR Broadley and PJ White, editors]. Oxford: Blackwell.

Yang FM, Chen LC, Hu QH \& Pan GX (2003) Effect of the application of selenium on selenium content of soybean and its products. Biological Trace Element Research 93, 249-256.

Yläranta T (1984a) Raising the selenium content of spring wheat and barley using selenite and selenate. Annales Agriculturae Fenniae 23, 75-84.

Yläranta T (1984b) Effect of selenium fertilization and foliar spraying at different growth-stages on the selenium content of spring wheat and barley. Annales Agriculturae Fenniae $\mathbf{2 3}$ 85-95.

Yläranta T (1984c) Effect of selenite and selenate fertilization and foliar spraying on selenium content of timothy grass. Annales Agriculturae Fenniae 23, 96-108.

Yoshimoto N, Takahashi H, Smith FW, Yamaya T \& Saito K (2002) Two distinct high-affinity sulfate transporters with different inducibilities mediate uptake of sulfate in Arabidopsis roots. Plant Journal 29, 465-473.

Zhang Y, Pan G, Chen J \& Hu Q (2003) Uptake and transport of selenite and selenate by soybean seedlings of two genotypes. Plant and Soil 253, 437-443. 